\title{
Moving The Masses: Emotion Work In The Chinese Revolution
}

\section{Citation}

Perry, Elizabeth J. 2002. Moving the masses: Emotion work in the Chinese revolution.

Mobilization 7 (2): 111-128.

\section{Permanent link}

http://nrs.harvard.edu/urn-3:HUL.InstRepos:11591713

\section{Terms of Use}

This article was downloaded from Harvard University's DASH repository, and is made available under the terms and conditions applicable to Other Posted Material, as set forth at http:// nrs.harvard.edu/urn-3:HUL.InstRepos:dash.current.terms-of-use\#LAA

\section{Share Your Story}

The Harvard community has made this article openly available.

Please share how this access benefits you. Submit a story.

\section{Accessibility}




\title{
MOVING THE MASSES: EMOTION WORK IN THE CHINESE REVOLUTION*
}

\author{
Elizabeth J. Perry
}

\begin{abstract}
Previous explanations of the Chinese Communist revolution have highlighted (variously) the role of ideology, organization, and/or social structure. While acknowledging the importance of all these factors, this article draws attention to a largely neglected feature of the revolutionary process: the mass mobilization of emotions. Building upon pre-existing traditions of popular protest and political culture, the Communists systematized "emotion work" as part of a conscious strategy of psychological engineering. Attention to the emotional dimensions of mass mobilization was a key ingredient in the Communists' revolutionary victory, distinguishing their approach from that of their Guomindang rivals. Moreover, patterns of emotion work developed during the wartime years lived on in the People's Republic of China, shaping a succession of state-sponsored mass campaigns under Mao. Even in post-Mao China, this legacy continues to exert a powerful influence over the attitudes and actions of state authorities and ordinary citizens alike.
\end{abstract}

The stunning victory of the Chinese Communists in 1949, which occurred more swiftly and decisively than either side anticipated, has sparked a good deal of analysis and debate among students of revolution. For the most part explanations have focused on ideological issues, arguing variously that it was a commitment to nationalism, land reform, or some combination of the two that accounts for the Communists' impressive success vis a vis their Guomindang rivals (Snow 1963; Taylor 1940; Johnson 1962; Hinton 1967; Selden 1971; Kataoka 1974; Pepper 1978). To a lesser extent, scholars have stressed the organizational superiority of the Communists (Hofheinz 1977; Chen 1986). Recently, attention has also been directed at the powerful role of symbols and myths in fueling the Communist advance (Wasserstrom 1991; Apter and Saich 1994).

Undoubtedly, ideology, organization, and symbolism culture all played crucial roles in the revolutionary process. So too did structural factors such as class cleavages, international pressures, and state weakness (Moore 1966; Skocpol 1979). And yet one could argue that the Communists and Guomindang actually shared more similarities than differences on all these dimensions. Both parties (which had been founded along classic Bolshevik lines) embraced the nationalist cum revolutionary program of Sun Yat-sen, both espoused opposition to imperialism and support for land reform, both advocated state-led industrialization, both esteemed the memories of the 1911 Revolution, the May Fourth Movement, the Northern

\footnotetext{
* For helpful comments on an earlier draft, I am indebted to Paul Cohen, Nara Dillon, Jacques Hymans, Arthur Kleinman, Naunihal Singh, Julia Strauss, Patricia Thornton, Jeffrey Wasserstrom and members of Harvard University's Political Psychology and Behavior Workshop and Comparative Politics Workshop. My apologies to all of these constructive critics for failing fully to address their complaints in this revised version. My thanks also to Victor Shih and Tina Wang for research assistance.

${ }^{\dagger}$ Elizabeth J. Perry is Professor of Government and Director of the Fairbank Center for East Asian Reserach, Harvard University, 1737 Cambridge Street, Cambridge, MA. 02138. E-mail: eperry@latte.harvard.edu

(C) Mobilization: An International Journal, 2002, 7(2): 111-128
} 
Expedition, and other legendary milestones in the revolutionary saga, and both operated in the same explosive setting.

If the political vocabulary and structural environments of the two parties were remarkably congruent, the same cannot be said of the response that they evoked from ordinary Chinese. While the dashing "Christian Generalissimo" Chiang Kai-shek and his Wellesleyeducated wife may have been the darlings of the American press and Congress, their reception back home was a different story altogether. In China it was the earthy peasant Mao Zedong who moved his compatriots, first to tears and anger, and then to revolutionary action.

The glaring disparity in the outcomes of the Communist [CCP] and Guomindang [GMD] movements points to a more general lesson that students of revolutionary politics have only recently begun to address: the translation of radical ideas and images into purposeful and effective action demands not only conducive environmental conditions, but also substantial emotional engagement on the part of leaders and followers alike (Gamson 1992; Taylor 1995; Aminzade and McAdam 2001). Indeed, the Chinese case can be read as a textbook illustration of how emotional energy may (or may not) be harnessed to revolutionary designs.

In contrast to the publicly restrained Chiang Kai-shek, Mao Zedong was a master at connecting passion and politics. But it was not only at the elite leadership level that we can detect such differences. The two revolutionary efforts differed from top to bottom in the extent to which they relied upon what Hochschild has termed "emotion work" - or "the act of trying to change in degree or quality an emotion or feeling"-in pursuing their goals (Hochschild 1979). Through such techniques as "speaking bitterness" (suku), "denunciation" (kongsu), "criticism-self criticism" (piping-ziwo piping), "rectification" (zhengfeng) and "thought reform" (sixiang gaizao), the Chinese Communists-in stark contrast to their Guomindang opponents - heightened emotional commitment among cadres as well as ordinary recruits to their cause. The dedication born of this "emotion-raising" (tigao qingxu) was a key ingredient in the campaigns against Japanese soldiers and Chinese landlords alike. The millions who enlisted on the side of the Red Army were probably motivated less by some abstract affinity for the principles of nationalism or land reform than by heartfelt allegiance to a highly charged crusade.

How did the Communists succeed in generating such devotion? And, equally important, what were the long-term effects of their methods of revolutionary mobilization? This article will examine the process and legacy of Communist "emotion work" through reconsideration of the major mass campaigns of the revolutionary and post-revolutionary eras. Eyewitness accounts of land reform, while highlighting the ideological aims of the movement, nevertheless provide valuable information on ways in which the Communists encouragedindeed demanded - public expressions of anger, fear, and shame (Myrdal 1965; Hinton 1967; Snow 1963; Crook and Crook 1979; Endicott 1991). Cadre handbooks offer more detailed guides to the specific steps involved in mobilizing emotional energy for revolutionary purposes (Li 1942).

As previous scholars have noted, such techniques drew creatively upon dominant themes in Chinese political discourse that emphasize group - more than individual - bases of morality (Lifton 1963; Cialdani 1993; Solomon 1971). The Confucian stress upon social bonds and obligations made group ostracism a particularly potent form of emotional discipline. ${ }^{1}$ Building a sense of collective solidarity, in China as in other societies, was a fundamental element of revolutionary mobilization.

Although the emotional intensity required for the expropriation of land (and execution of landlords) could not be sustained indefinitely, it was rekindled during subsequent campaigns-well after the political victory of the CCP in 1949. The paper will trace ways in which the patterns of emotion work developed during the wartime years lived on in the People's Republic of China, deeply influencing such initiatives as the Suppression of Counter-Revolutionaries, the Anti-Rightist Campaign, the Great Leap Forward and the 
Cultural Revolution. A hallmark of the Maoist period was the attempt to "continue the revolution," applying lessons from the pre-1949 struggle to new goals of economic development and political consolidation. Even in the contemporary post-Mao era, such legacies are far from irrelevant to an understanding of Chinese political dynamics. But techniques that proved highly efficacious in the battle against landlords and Japanese invaders yielded quite different results in the changed circumstances of the post-revolutionary scene.

\section{MOBILIZING THE REVOLUTION: PEASANTS}

Of course, the use of emotional fervor in mass mobilization was not an invention of the Chinese Communists. For centuries before the advent of the Red Army, peasant uprisings had drawn upon a panoply of folk techniques - martial arts routines, breathing regimens, spirit possession, sworn oaths, operatic performances, and the like - whose effect was to strengthen the emotional resolve of participants (Chesneaux 1973; Esherick 1987). Both Peng Pai and Mao Zedong, as early leaders of the Communists' peasant movement, expressed high regard for indigenous repertoires of rural resistance and advocated that such traditions be redirected toward revolutionary ends (Galbiati 1985; Mao 1971: 23-39).

While it is not clear that previous rebel leaders were entirely cognizant of the role of "emotion work" in generating popular enthusiasm for their enterprise, the Communists were quite deliberate in their use of such tactics. The growth of the revolutionary movement was marked by increasing attention to the importance of "emotion-raising" in the process of mass mobilization.

Theater was a critical means of eliciting an emotional reaction that was used intentionally to solidify popular commitment. A propaganda worker in the Jiangxi Soviet recalled of the make-shift dramatic performances that were staged to generate support for the Red Army:

When the audience watched comic scenes they laughed loudly; when they watched tragic scenes they lowered their heads and wept or angrily denounced the landlords. Thus we knew that the drama had deeply stirred the audience, achieving propaganda results. How happy we were then! (Pan 1962: 146)

Once moved by such performances, peasant recruits were encouraged to articulate their own accusations against their former oppressors. As a propaganda worker in the Northeast noted, "We felt that speaking bitterness was extremely effective in stimulating class hatreds and heightening feelings of vengeance.... The purpose of war became clear, and the emotions of the troops were raised" (Mo 1991: 194).

American journalist Edgar Snow, who interviewed Communist leaders after their epic Long March, also highlighted the role of theater in the Communists' mobilization drive: "There was no more powerful weapon of propaganda in the Communist movement than the Reds' dramatic troupes, and none more subtly manipulated.... When the Reds occupied new areas, it was the Red Theater that calmed the fears of the people, gave them rudimentary ideas of the Red program, and dispensed great quantities of revolutionary thoughts, to win the people's confidence" (Snow 1963: 123-124). The use of theatrical performances to mobilize the masses grew out of an old tradition that linked rural opera and peasant protest (Esherick 1987). In the early twentieth century, prior to the advent of the Communists, spoken drama (as opposed to opera) became a powerful means of communicating revolutionary messages (MacKerras 1975: 48-49).

Drama was not merely one tactic in an arsenal of mass mobilization methods; it was, in a sense, a metaphor for the entire enterprise (Turner 1974; 1982). Staged public performances have constituted the very heart and soul of the Chinese Communist revolution, 
from the days of land reform right down to the 1999 campaign against Falun Gong. ${ }^{2}$ This is not to imply, however, that the emotions expressed in such contexts are somehow phony or inauthentic. A distinctive facet of human feelings is their ambivalence and malleability; the genius of the CCP approach lay in its capacity to appreciate and capitalize on this fundamental reality.

If the Communists learned the rudiments of emotion work during the Jiangxi period (1928-34) and subsequent forced march to Yan'an, they put the lessons to good use in the war against Japan (1937-45). The land reform that proved so crucial to the establishment of wartime base areas was introduced to the peasantry by carefully orchestrated struggle sessions. As Chen Yung-fa's definitive study indicates, the land revolution unfolded as a kind of mass theatrical performance whose purpose was to harness emotional excitement to the Communist cause:

Having chosen the targets, the party called all local cadres and activists into a mobilization meeting to explain the decision and assign each a role. The mass workers announced the targets, presented the accusations and evidence, and tried to stir anger against the targets. Then a division of labor was formalized. A mass worker assigned activists to be chairman, chief accuser, second accuser, guards, master of ceremonies, and accountant, and coached the activists on how to perform their assigned jobs.... Sometimes activists were specially assigned to stir up public indignation....

Finally the big day arrived. Peasants were mobilized to attend the struggle meeting. The target was brought in. The chairman made a brief speech about the meaning of the struggle meeting. And then the victims charged their abusers, pointed accusing fingers, screamed, and wept. Secondary accusers could then stand up and give their testimony. The atmosphere of rage was further heightened by slogan shouting. Peasants who had harbored grudges against the target, but out of moral reservations or mortal fear had suppressed them, now suddenly felt unable to restrain their indignation. Assured of sympathetic ears and powerful support, they lashed out, and even those who did not harbor grudges felt sympathy and sought ways to express it (Chen 1986: 186-187).

The size of a struggle meeting was a key variable in determining its emotional climate: "When only a few dozen people were present, the mass worker usually found little response to emotional charges against a target, but, in an agitated group of hundreds or thousands, peasants soon forgot their vulnerability... and acted like totally different people. They became bold and aggressive" (Chen 1986: 187).

Active mass involvement was a hallmark of Mao's revolution, but as Mao and his lieutenants understood, it was easy for large, emotionally charged convocations to get out of hand. Thus an important item in cadre training concerned the prevention of "leftist excesses." Although mass violence was accepted, and sometimes even celebrated as an integral part of the revolutionary process, physical force was to be used strategically rather than indiscriminately. ${ }^{4}$

Violence, if appropriately applied, could have the effect of releasing previous inhibitions by suddenly reversing the perception of authority relations. ${ }^{5}$ William Hinton's sympathetic account of the land reform in Long Bow Village reveals the reluctance of peasants to voice their grievances until a cadre's slap altered the local balance of power:

The silent crowd contracted toward the spot where the accused man stood.... The peasants were listening to every word but gave no sign as to 
how they felt.... no one moved and no one spoke. "Come now, who has evidence against this man?" Again there was silence. Kuei-ts'ai, the new vice-chairman of the village, found it intolerable. He jumped up, struck Kuo Te-yu on the jaw with the flat of his hand. "Tell the meeting how much you stole," he demanded.

The blow jarred the ragged crowd. It was as if an electric spark had tensed every muscle. Not in living memory had any peasant ever struck an official....

The people in the square waited fascinated, as if watching a play. They did not realize that in order for the plot to unfold they themselves had to mount the stage and speak out what was on their minds (Hinton 1967: 112-114).

After a night of tense meetings in which "some people were so excited they did not sleep at all," Hinton reports that the following day "hundreds of accusations" came pouring out against the party-selected targets, who were then taken to a field at the edge of a village and shot (Hinton 1967: 115-117). ${ }^{6}$

Once cadre activists had opened the door to emotional contestation, village women were often the first to enter the fray. Their gender having accustomed them to an expressive mode of communication, women inveighed against past injustices with particular fervor. As Hinton observes, "by 'speaking pains to recall pains,' the women found that they had as many if not more grievances than the men and that once given a chance to speak in public they were as good at it as their fathers and husbands" (Hinton 1967: 157).

The reactions of the masses were not the cadres' only concern in these struggle sessions; the targets of attack might also prove problematic. Those who were selected as victims for public criticism, it was emphasized, should be neither overly recalcitrant nor unduly acquiescent. As Chen Yung-fa explains, "Defiance by a stubborn target might result in a deadlock. To save the situation, the mass worker was asked to intervene in such a way as to give peasants a sense of assurance.... Because a struggle meeting without resistance excited few peasants, the party also cautioned against choosing easy objects" (Chen 1986: 189).

Although — or rather precisely because - the struggle meetings were cleverly choreographed, the emotional impact on participants was obviously intense. Accounts of Communist-directed land reform concur in stressing the catalytic role of fear, grief, rage and revenge in energizing the course of popular participation. ${ }^{7}$ Appeals to sentiments of fairness (gongping) also figured centrally in the process (Chen, Xue, and Ma 1985). ${ }^{8}$

Crucial as mass mobilization was to the Communist effort, it is important to remember that the Communists were not the only self-proclaimed Chinese revolutionaries to undertake such campaigns. In the late 1940s, while still struggling against the CCP on the mainland, the GMD launched a "liquidate traitors' campaign" (xiaojian yundong) intended to ferret out enemy forces within the industrial proletariat. Much like the Communists, the Guomindang authorities declared that "there are no genuine traitors among our workers, just people being used by traitors." The goal of the campaign was to encourage confessions of wrongdoing by Communist fellow-travelers. In contrast to the CCP, however, GMD campaign directives called not for emotional denunciations but rather for the cultivation of "high-minded character" and "a resolute will." The emphasis was decidedly ethical, rather than emotional (Shanghai Municipal Archives \#Q6-31-132).

After retreating to Taiwan, the Guomindang initiated other explicitly political mass campaigns. A cadre handbook on mass movements, published in Taipei in 1954 by the Central Committee of the GMD, gave detailed instructions on how to implement the "AntiCommunism Anti-Russian Mass Campaign" (fangong kang'e minzhong yundong) that had recently been announced on Taiwan. But if the outward form of mass movements on both 
sides of the Straits was surprisingly similar, the actual methods of implementation differed markedly. Tellingly, the handbook for GMD cadres includes lengthy discussions of ideology (yishi), policy (zhengce), organization (zuzhi), and leadership (lingdao) - but not a word about emotions (Guomindang 1954).

\section{EXTENDING THE REVOLUTION: WORKERS}

On the mainland, however, the practices of emotion work developed during the revolutionary era were systematized and standardized after the political victory in 1949. Techniques that had proven effective in the course of land reform were now extended to an urban context as well. Thus the campaign to suppress counter-revolutionaries, which swept across Chinese cities during the Korean War, was carried out by means of speak-bitterness and accusation meetings of the very sort that had long characterized the rural revolution. To familiarize urban cadres with these procedures, internal-circulation bulletins were issued, spelling out in detail the steps involved in organizing such events. ${ }^{9}$ The circulars stressed that a prerequisite to success lay in overcoming "tenderheartedness" (wenqingzhuyi); workers must be made to realize that benevolence toward counter-revolutionaries was tantamount to cruelty toward the people. The purpose of the mass meetings was to arouse sufficient indignation on the part of ordinary people that they would participate actively - indeed gleefully - in the liquidation of designated class enemies. Moreover, they were then supposed to return to work with renewed enthusiasm for production. To ensure the proper results, emotion work would need to be carefully controlled by cadre leadership.

The instructions for union cadres stipulated that they must concentrate on "raising emotions" (tigao qingxu) and encouraging "gutsy accusations" (dadan kongsu). It was suggested that try-outs and dress rehearsals be held in order first to select the most convincing "hosts of bitterness" (kuzhu) and then to coach these protagonists on how to deliver their denunciations most effectively. Presentations needed to be short, succinct, and substantive (Shanghai Municipal Archives, \#B168-1-804: 43). The best hosts were said to be those with "representative qualities" (you daibiaoxing), who had suffered greatly at the hands of the alleged counter-revolutionaries. It was acknowledged that the hosts were likely to harbor misgivings about their performance; their fears might include wronging someone, meddling in other people's affairs, provoking revenge, losing face, or simply being a poor public speaker. Cadres needed to be sensitive to such concerns so that they could alleviate doubts and promote activism. When organizing accusation meetings among Christian converts, for example, cadres tried to overcome their initial reluctance to cast the first stone by reminding the faithful that Jesus himself had used accusation methods against the Pharisees! (Shanghai Municipal Archives \#B168-1-804: 43). Those who were chosen as hosts of bitterness were also encouraged to offer one another suggestions during the dress rehearsal so that they would all prove as persuasive as possible during their presentations, "capable of stirring up grudges" (neng jiqi chouhen) and "exciting mass passions" (gudong qunzhong qingxu).

Before the mass meeting was convened, "all means of propaganda"-big-character posters, broadcasts, recreational activities, group and individual discussions, and the likeshould be employed so as to prepare ordinary participants for the occasion. It was recommended that an exhibit be set up adjacent to the meeting hall to display bloody clothes and other personal effects belonging to victims of the accused, along with weapons used by the perpetrators and sketches and photographs of their crimes. Inside the hall, banners made of black cloth with white lettering and blue borders (reminiscent of funeral regalia) were to be hung together with cartoons depicting criminal activities. The combined effect, it was said, would create an atmosphere at once "solemn yet lively."

Tickets were to be issued in advance, to exclude those who had "reactionary" connections, so that the masses would feel no inhibitions ( $g u l \ddot{u}$ ) in speaking out. During the meeting itself, the chair was enjoined to pay close attention to controlling the emotional 
climate. Meetings were to last no longer than an hour and fifteen minutes so as to avoid the tedium that might otherwise set in. At appropriate moments, songs taught to the workers beforehand might be intoned to enliven the proceedings. These were to be led by preappointed propaganda team members. Additionally, party and youth league members should be scattered among the audience to assist in shouting slogans. Such slogans must be brief and easily grasped; those who led in shouting them should be carefully selected beforehand on the basis of their standing among the masses as well as their clear and forceful voices. The point was to stir up emotions, but not to dissolve into disorder.

It was emphasized that the lead-off host of bitterness must be particularly dramatic, so as to capture audience attention from the start. Since such emotional intensity could not be sustained indefinitely, subsequent accusers might be a bit less gripping. However, it was essential to "re-tighten" before the end of the meeting to ensure that the audience would depart with lasting sentiments of grief and indignation (beifen). One criterion of a successful meeting was that it had "spared no one's feelings" (pochu qingmian) (Shanghai Municipal Archives \#B169-1-804: 43). Preferably, the meeting would adjourn before all hosts had delivered their accusations, thereby preserving a sense of unfinished business.

Workers whose bodies bore the marks of torture were favored for the lead-off role as hosts of bitterness. At the Number Six Cotton Mill, a worker whose hand had been severed by the accused initiated the criticism. After mounting the stage, the one-handed worker removed his clothes to reveal the scars of wounds inflicted by the culprit. He was then followed by several women who burst into tears while shouting their denunciations. Sobbing, the entire audience began to scream in one voice to demand immediate death for the accused.

The success of an accusation meeting could be gauged by the level of enthusiasm that the masses demonstrated in carrying out the appointed executions. The railway union reported with evident satisfaction that, following a mass meeting at which eight counterrevolutionaries were sentenced to death, participants were so riled up that they stomped on the heads of the victims after their execution by firing squad at a nearby park. Seeing that some relatives of the deceased had dissolved into tears, the accusers yelled out, "Why cry? To die by a single bullet is too good for the likes of them. If you cry, we'll laugh!" (Shanghai Municipal Archives \#C1-2-397). Such emotional states allegedly had a utility that outlasted the act of killing; they were deemed beneficial for production as well. The railway union noted that on-the-job enthusiasm had increased markedly after this searing event.

Emotional excitement was essential to mass activism, but it was also inherently dangerous. In more than a few instances, workers fired up by the fervor of the Suppression of Counter-Revolutionaries Campaign took matters into their own hands, attacking suspects without the prior approval of public security authorities. Such spontaneous expressions of mass justice helped underscore the importance of bureaucratic control.

\section{DISCIPLINING THE REVOLUTION: ELITE RECTIFICATION}

Mass criticisms, and the public executions of landlords and counter-revolutionaries that often followed in their wake, were a highly visible yet inherently ephemeral way of harnessing emotional energies to revolutionary ends. In other times and places, emotional mobilization has proven notoriously difficult both to sustain and to prevent from devolving into sectarian strife led by competing elites (Gough 1998; Stunt 2000). In the Chinese case, less public yet more enduring methods were developed to strengthen and discipline the resolve of those whose continuing service to the revolutionary cause was deemed essential: party members and intellectuals in particular.

During the wartime era, alongside the speak-bitterness and accusation sessions in which peasants - under party direction - found a collective voice with which to denounce their oppressors, other procedures were devised to handle intra-party discipline. In the early 1940s, a Rectification (zhengfeng) movement was directed at party cadres themselves. ${ }^{10}$ 
Undertaken in all the Communist base areas, the Rectification Campaign required party members - after studying assigned documents in small groups - to prepare confessions detailing the ways in which their own thoughts and actions had strayed from official standards (Selden 1971:188-200). At first, self-criticism did not come easily: "Aversion to confession seemed to be universal, and the party branch secretary had to do something to alleviate the participants' fears ... Personifying the party as a benevolent father helped the participants in the rectification class make great headway in revealing their inner thoughts" (Chen Yung-fa 1986: 335-337). Recalcitrants were not only encouraged by the promise of paternalistic leniency to those who made a clean breast of things; they were also subjected to intense group pressure until they complied with party demands. As Mark Selden explains, the rectification process revealed an astute grasp of the fundamentals of social psychology:

Recent studies of group dynamics underline the immense psychological power groups can wield over their members. In particular, one is impressed by the awesome pressures to conform to group norms experienced by individuals who are unanimously declared "sick" or insane. The "patient" is able to save himself, in the sense of restoring his own self-esteem as well as being reincorporated into the group, only by demonstrating complete acceptance of group values and norms. These pressures were effectively increased in the rectification movement through small-group study and discussions that included the criticism of every cadre by his peers and searching self-criticism (Selden 1971: 195).

The use of group- and self-criticism in party rectification was rather different from the mass criticism sessions that served as a prelude to the executions of landlords or counterrevolutionaries. For one thing, the process was carried out behind closed doors. For another, the purpose of rectification was to educate - rather than to eliminate - the targets of struggle (Writing Group 1988; Zhang 1958; Zhong 1957).

As we have seen, Land Reform and the Suppression of Counter-revolutionaries Campaign proved effective in disposing of enemies from the pre-Communist era. But, as the Hungarian Revolt of 1956 indicated so graphically, socialism engenders its own contradictions. Profoundly shaken by events in Budapest (and Warsaw as well), Mao called upon the Chinese people to engage in a Hundred Flowers Campaign intended to eliminate "bureaucratism" and related shortcomings of his Communist regime. Intellectuals in particular were encouraged to raise complaints about official misconduct, after which chastened cadres were expected to undertake reflection and reform. When the winds of popular criticism blew more furiously than Mao had anticipated, however, the Hundred Flowers gave way to an Anti-Rightist Campaign directed against those who had dared to voice opinions deemed beyond the pale by party authorities.

If the Hundred Flowers had been intended as a relatively mild variant of rectification, the Anti-Rightist Campaign of 1957 was its monstrous stepchild. During the campaign, rectification methods of group- and self-criticism were refined and elaborated into a full-blown program of thought reform (or "brainwashing" as it was called by its detractors). Hundreds of thousands of intellectuals were packed off to labor reform camps, euphemistically dubbed "revolutionary universities," where they were subjected to a relentless regimen of group criticism to be followed by personal confession. Although the goal was rehabilitation, the process was brutal. Solitary confinement, chains, and torture were often an integral part of the experience.

Robert Lifton, a Yale psychiatrist who interviewed dozens of thought-reform veterans, writes that the procedure "aimed at breaking down every emotional identification which could interfere with the full acceptance of the new Communist identity" (1963: 383384). Often this goal was attained. As Lifton discovered, many of those who went through the 
ordeal "underwent a profound religious experience. They regarded thought reform as fine and ennobling and felt genuinely reborn, along with their society. The zealous convert was usually youthful, either an adolescent or a young adult" (Lifton 1963: 400).

How was this sometimes remarkably successful process developed? Lifton stresses that thought reform was not the brainchild of professional psychologists, whether Russian or Chinese. There is no evidence that social scientists or medical specialists played any significant role in devising these powerful techniques. According to Lifton, the quasi-religious flavor of the approach (which highlighted feelings of sin and guilt that are quite alien to the Chinese tradition) may have come from Russian methods of extracting confessions from condemned prisoners. Nevertheless, Lifton emphasizes that Chinese thought reform differed sharply from Soviet practices in that the Chinese insisted on the possibility of re-education. Whereas Soviet prisoners were to be shot once they had confessed, those subjected to Chinese thought reform were expected to emerge reborn as committed converts to Communism. This distinction was evidently related to a Confucian emphasis (consistent with MarxismLeninism) on the fundamental malleability and perfectibility of human beings (Lifton 1963: chapter 20; Munro 1977). The traditional belief in education (effected in large part through social pressure) shaped a variety of Chinese Communism quite unlike its Soviet exemplar:

Nor were Chinese improvisations always approved by Russian advisors: Chang [the early Communist leader, Zhang Guotao] mentioned that on several occasions Chinese Communist leaders were criticized for being "too much influenced by Confucian ethics." Yet this moral and psychological emphasis seemed to come naturally to them; according to Chang, they were "good psychiatrists." And although the Nationalists made similar efforts to "reform" Communists and Communist sympathizers in special "repentance camps," their efforts were (according to Chang and many other observers) much more clumsy and much less effective ( Lifton 1963: 395).

Why the Communists proved so much more adept at emotion work than their Guomindang opponents is not entirely clear, but several considerations come to mind. For one thing, Communist cadres tended to issue from somewhat lower socioeconomic backgrounds than their Nationalist counterparts, thereby putting them on a closer footing (culturally and psychologically, and materially) with most of the people they were attempting to mobilize (North 1952). For another, the Guomindang's persistent tendency to identify popular mobilization with Communist influence intensified their own distance from the masses.

Mao Zedong himself was intensely attuned to the importance of human psychology-including the elitist mentality of Chinese intellectuals - and devoted much of his writings to an exploration of its role in revolutionary transformation. Mao's idiosyncratic interpretation of the key Marxist concept of class assigned far more weight to changeable emotional identities than to objective economic position. As he wrote at the start of the Rectification Campaign in 1942:

If you want the masses to understand you, if you want to be one with the masses, you must make up your mind to undergo a long and even painful process of tempering. Here I might mention how my own feelings changed. I began life as a student and at school acquired the ways of a student; I then used to feel it undignified to do even a little manual labor, such as carrying my own luggage in the presence of my fellow students, who were incapable of carrying anything, either on their shoulders or in their hands. At that time I felt that the intellectuals were the only clean people in the world, while in comparison workers and peasants were dirty.... But after I became a revolutionary and lived with workers and peasants and with soldiers of the 
revolutionary army, I gradually came to know them well, and they gradually came to know me well too. It was then, and only then, that I fundamentally changed the bourgeois and petty-bourgeois feelings implanted in me in the bourgeois schools. I came to feel that compared with the workers and peasants the unremoulded intellectuals were not clean and that, in the last analysis, the workers and peasants were the cleanest people and, even though their hands were soiled and their feet smeared with cow-dung, they were really cleaner than the bourgeois and petty-bourgeois intellectuals. That is what is meant by a change in feelings, a change from one class to another (Mao 1971: 255).

But Mao was not content to limit his emotional crusade to party members or intellectuals; he was insistent that the entire country should feel a similar degree of enthusiasm for the revolutionary cause. Mass ecstasy, Mao believed, was efficacious not only for revolutionary struggle, but for dramatic economic breakthroughs as well.

\section{MAO'S MASS CAMPAIGNS}

The Great Leap Forward was launched in 1958 as an effort to permit China to leap-frog overnight from agrarian backwardness to industrialized communism. Arguing that mass enthusiasm could jump-start the stalled economy, Mao boasted that China would soon surpass first England, and then the United States, in steel production. The atmosphere of the Great Leap was almost millenarian, with Mao promising to lead his countrymen toward a superhuman breakthrough. Disappointed by the response of intellectuals during the Hundred Flowers Campaign, the Chairman returned now to a more reliable constituency: the peasantry. As it turned out, however, methods that had worked wonders in eliminating class enemies during Land Reform were not equally suited to the sober task of economic development. The results fell tragically short of Mao's fantasies, plunging the Chinese countryside into the worst famine in human history.

Nothing symbolized the folly of the Great Leap more vividly than the ill-fated backyard steel furnaces. An English visitor to China in the autumn of 1958 reported,

We walked through the paddy fields to another village where four monstrous home-made blast furnaces had been rigged up. The place was a furious, seething, clattering scene of frenzy. People carried baskets of ore, people stoked, people goaded buffalo carts, people tipped cauldrons of white hot metal, people stood on rickety ladders and peered into furnaces, people wheeled barrows of crude metal - though to me the stuff that was being poured out at the bottom of the furnaces looked exactly like the stuff that was being poured in at the top (Wollaston 1960: 115)

To organize this colossal (waste of) effort, "people's communes" were formed. The new institution, whose name suggested the ultimate fulfillment of Marxist prophecies, heightened the sense of chiliastic anticipation. As a grassroots cadre in Southeast China recalled of the quasi-religious atmosphere,

At that point everyone seemed to be caught up by this frantic socialist devotion. Nobody had any doubt that we could achieve these goals. Was it not true that we had already entered the final Communist stage when we organized these rural communes? A paradise materialized through the guidance of the party and Chairman Mao. I was a true believer then.... The Liberation brought to us our rebirth (Huang 1989: 58-59). 
Mass devotion and enthusiasm, it turned out, was no substitute for economic infrastructure. The thirty million casualties of the Great Leap Forward were horrible proof of the limits of this precipitous approach to industrialization.

But if the material base was resistant, might not the superstructure prove more amenable to mass transformation? In the years following the debacle of the Great Leap, Mao turned his attention to questions of ideology and culture - a preoccupation that eventuated in 1966 in the launching of the Cultural Revolution. Aware perhaps that frenzied campaigns were reaching a point of diminishing returns among the peasantry, Mao reached out to a less jaded audience. In this, his final crusade, the Chairman called upon the most impressionable and malleable members of society - the youth of China - to take up the revolutionary torch.

The so-called madness of the Cultural Revolution did not emerge out of nowhere (White 1989). Activists in the Cultural Revolution were quite self-conscious in drawing upon earlier repertoires of contention. Gao Yuan recalls in his autobiographical account of Red Guard experiences that, when it came time to launch struggles against "capitalist roaders" at his school, the secretary of his class Youth League "suggested we take inspiration from Chairman Mao's report on the peasant movement in Hunan province, written in the 1920s, which described how the peasants had put dunce caps on the heads of local tyrants and evil gentry and paraded them through the streets" (Gao 1987: 50). Similarly, Yue Daiyun observes in her memoir of the Cultural Revolution at Beijing University that " $[t]$ he idea of parading enemies had originated in the 1920s when the Communist Party, pursuing its work among the peasants, often forced the landlords to march in front of those they had formerly oppressed, every landlord wearing a tall, pointed hat bearing a description of his wrongdoing. Now in the frenzy of the moment, the students had no time to fashion enough hats, so they used wastebaskets instead ..." (Yue and Wakeman 1985: 157).

Cultural Revolution methods of mass criticism took inspiration from urban, as well as rural, traditions of protest. As Jeffrey Wasserstrom has observed, student protesters in the May Fourth Movement of 1919 organized mass rallies, shouted slogans, staged public parades, delivered streetside harangues, and pasted up condemnatory wall posters (Wasserstrom 1991: Chapter 3). ${ }^{11}$ Factory workers could also lay claim to a colorful, and evidently still accessible, heritage of struggle. It was probably no coincidence that Shanghai's Number Seventeen Cotton Mill, where rebel commander Wang Hongwen worked, had in the mid-1920s been the scene of labor violence strikingly similar to that of Cultural Revolution criticism sessions. In a 1925 incident at the factory, workers had tricked a hated foreman into attending a mass meeting at which he was publicly denounced. The hapless foreman was forced to kneel in front of the crowd with hands tied behind his back (in what came to be known during the Cultural Revolution as the painful "airplane position"), a dunce cap was placed on his head, and a placard reading "Down with this traitor and running dog" hung across his chest. Photographs of the occasion were posted at the factory gate to serve as warning lest the unseated overseer ever try to resume his post (Zhang 1953: 61-70).

Liang Heng's eyewitness account of a Cultural Revolution mass criticism session indicates the unmistakable continuities with previous patterns of struggle:

There were all kinds [of criticism meetings], every day, big and small, but the one that made the deepest impression on me was the sort called "traveling struggle." It was a lot like the way the People's Liberation Army had dealt with the landlords after Liberation (I'd seen that in movies), but even more cruel.

The loudspeaker called us all outside, and in a few minutes I saw it coming. A group of Rebels were in the lead shouting "Down with the Capitalist Roaders" and "Long Live Chairman Mao Thought." Following them were about ten of the old "leading comrades" tied together on a long rope like 
beads on a string, their hands bound. They were wearing tall square-topped paper hats inscribed with phrases like I AM A BASTARD or I AM A FOOL, and around their necks were wooden signs with their names and crimes....

The Capitalist Roaders [knelt] on the platform, their hands tied behind their backs with long ropes.... [T] hey had to recite the big character posters attacking them. The meeting went on and on, and whenever someone stumbled there were cries of "Give him an airplane ride, give him an airplane ride!" At this the Rebels tossed the rope binding the man's arms behind him over a pipe at the top of the auditorium and hoisted him up in the air, letting him squirm in agony like a dragonfly with pinched wings (Liang and Shapiro 1983: 77-79).

But if the form of the Cultural Revolution was patterned closely on earlier revolutionary exemplars, the substance was vastly different. Occurring in a context where landlords and capitalists had already been eliminated, much of the campaign involved the manufacturing of subjectively defined class enemies.

Even more than in previous instances of mass mobilization, the Cultural Revolution relied on emotional transformation as a catalyst for carrying out these cruel acts. As Richard Madsen has argued, "ceremonies of innocence" were often superseded by "rituals of struggle" over the course of this decade-long campaign (Madsen 1984). The Cultural Revolution showed yet again, if further proof were required, just how volatile and fluid individual emotions can become in the context of group politics. Former Red Guard Gao Yuan described his contradictory feelings when the spearhead of struggle was pointed at one of his favorite teachers, a kindly man by the name of Li: "I tried to push my liking for Li out of my mind and concentrate on his crimes. The latest posters had accused him of yearning to 'change the heavens,' to return to the old days, to restore Kuomintang rule... As I thought of these things, I began to hate Teacher Li. Yet part of me still liked him" (Gao 1987: 51).

The plasticity and ambivalence of human emotions helps perhaps to make sense of some of the more shocking dimensions of the Cultural Revolution ordeal. Wang Youqin's sobering study of Red Guard violence finds that favored teachers could turn into despised targets of struggle, literally overnight. Moreover, Wang points out that some of the most vicious classroom cruelty was perpetrated by girls at elite middle schools (Wang 1995). Although the privileged background of these girls makes their sudden resort to violence especially shocking, it seems likely that turbulent adolescent emotions contributed to the unusual fervor with which they performed their Cultural Revolution roles. ${ }^{12}$ But age was hardly a barrier to emotional transformation; adults as well as adolescents proved highly susceptible to the power of collective suggestion. Furthermore, the disintegration of state authority that marked some periods of the Cultural Revolution permitted mass violence to unfold without the restraints of cadre supervision.

\section{CONCLUSION}

The struggle sessions of the Cultural Revolution represented the apotheosis of the emotion work that had fueled the Communists' revolution from its earliest days. While the Communists had built upon pre-existing traditions of popular protest, they systematized such practices as part of a conscious strategy of political and psychological engineering. The link between violent acts and emotional liberation had been clearly recognized at the outset of the revolutionary process, perhaps as a product of the early Communists' fascination with anarchist ideas (Zarrow 1990; Dirlik 1991). During the build-up to the Three Workers' Armed Uprisings of 1926-27, for example, groups of armed workers roamed the streets of Shanghai 
with CCP approval as a kind of terrorist hit squad explicitly intended to "stimulate worker enthusiasm" for the revolutionary enterprise (Perry, forthcoming).

When the Communists had cultivated more of a popular base, they were able to move beyond terrorism to mass campaigns. But they never abandoned the commitment to emotion work, or for that matter to the use of violence, in exciting mass passions in service to larger political and economic goals. Although these efforts met with varying degrees of success, they suggest that CCP leaders appreciated what Western social scientists are only beginning to understand: emotions cannot be dismissed simply as a residual, irrational domain of consciousness. Rather, emotional gestures and utterances hold a unique capacity "to alter the states of the speakers from whom they derive." 13

The success of the Chinese Communists in developing and perfecting the art of mass mobilization goes some distance toward explaining their victory over the rival Guomindang. Although the Nationalists also made attempts to develop a popular following, they were hampered in these efforts by a conservative outlook that bespoke a deep distrust and fear of mass spontaneity (Hung 1994). As Paul Cohen has discovered in his study of national humiliation commemorations, as soon as the Nationalists gained political control in the spring of 1927, they moved swiftly to tame and formalize these expressions of mass emotion (Cohen 2002). Instead of permitting spontaneous public gatherings of national outrage and sorrow, as had previously been the practice, the GMD instructed schools, companies, and other units to send one or two delegates to highly routinized annual observances (Cohen, personal communication). In contrast to the CCP, the GMD recoiled at the prospect of mass action.

The Chinese Communists' skill at "moving the masses" also helps to highlight a key distinction between Chinese and Soviet variants of Communism. ${ }^{14}$ Whereas Stalin was content to rely upon the secret police to carry out his purges (Fitzpatrick 1999), Mao Zedong insisted upon popular involvement. Such widespread participation, he argued, was necessary in order to ensure the continuation of the revolution under socialism. Moreover, Mao believed that the emotional enthusiasm generated during these campaigns could be put to use in economic development as well. Energized by the disciplining of successive waves of counterrevolutionaries, the masses were expected to throw themselves into their jobs with renewed vigor. Rather than treating class struggle as a one-time event to be followed by a more relaxed brand of political and economic consolidation, the techniques of emotion work were deployed repeatedly (albeit targeted at and carried out by different groups) throughout Mao's reign.

Even in the post-Mao era, the legacy of mass mobilization continues to exert a powerful influence over the attitudes and actions of Chinese state authorities and ordinary citizens alike (Zhang 1987). According to the post mortem of a central participant, the Tiananmen protests of 1989 were fatally flawed by the students' own unconscious acceptance of many of the tenets of Maoist revolution (Liu 1994). Although the brutal suppression of that movement may have tarnished the reputation of the People's Liberation Army [PLA] in the eyes of many Chinese, within the space of a decade the government seemed to have largely erased such misgivings through an extraordinary campaign designed to eulogize the role of the PLA in fighting the disastrous floods of 1998. A propaganda blitz ranging from television programs and movies to dramas and ballets employed highly melodramatic techniques to depict the heroism and sacrifice of the soldiers. The outpouring of popular support that such performances elicited toward a government whose flawed policies of water conservancy deserved much of the blame for the calamitous inundations is surely related to the continuing skillful deployment of emotion work - now strengthened by the use of new media technology.

The practice of deploying emotion-laden mourning rituals for larger political purposes also lives on in new ways in contemporary China. During the May Thirtieth Movement of 1925, specially trained student troupes of mourners (e.g., the Kneel and Wail Corps of Tianjin) had gathered at mass memorial services to sob in unison (Wasserstrom 1991: 113). ${ }^{15}$ In April of 1989, the death of disgraced Party Secretary Hu Yaobang triggered the Tiananmen student demonstrations as protesters vied with officials to control the 
mourning ceremonies (Calhoun 1994). Fearful of a repetition of such challenges to authority, state authorities moved rapidly after the U.S. bombing of China's Belgrade embassy in May of 1999 to ensure that they would not be upstaged by nationalistic students. When the top leadership gathered to pay their respects to the deceased bombing victims, televised shots of a tearful Premier Zhu Rongji captured public attention.

The suppression campaign that party leaders launched against Falun Gong in the summer of 1999 offers further evidence of the lingering influence of a now modernized tradition of revolutionary "emotion work." Television broadcasts showed bereaved relatives of Falun Gong victims unburdening themselves of their strong feelings toward the alleged evil cult that had led their kinsmen astray. Sobbing denunciations of Master Li Hongzi blamed Falun Gong's supreme leader for the tragedies of insanity, suicide, starvation, and even murder that had befallen parents, children or spouse. While there is some doubt as to how effective this particular campaign will prove in the long run (or whether mass media can sustain the level of popular enthusiasm that was once generated by face-to-face dynamics), there is no question but that the Ministry of Propaganda's methods of conducting the initiative bore more than a family resemblance to previous mass campaign strategies (Perry 2000).

The government is not alone in being able to draw upon familiar techniques of emotional mobilization, however. Opponents of state policies may also turn to this tradition to muster resistance to official initiatives. Anthropologist Jing Jun discovered this phenomenon when investigating recent protests against government resettlement programs in a remote rural county in Northwest China:

In interviews about these protests, county officials noted with irony that the Communist "recalling-bitterness tradition," used to stir up grassroots resentment against the oppressiveness of the pre-Communist order, was now being employed by resettled villagers to air their grievances against Communist officials.... Commenting on this ritual's contemporary usages, one county official said, "The local masses really mastered our recallingbitterness tradition. But who could have expected that they would be using it against government workers today?" Other officials made similar complaints, lamenting that they could no longer visit the villages without being pursued by older women eager to tell them-with much wailing and cursing — how much they suffered (Jing 1999: 330-331).

The Communist Chinese repertoire of emotionally laden political rituals is thus a doubleedged sword that can be wielded not only by state officials, but also by disgruntled citizens.

To explain fully the origins, evolution, and contemporary implications of Communist Chinese emotion work will obviously require a much more detailed exploration than what I have attempted here. My hope, however, is that this preliminary discussion can serve to stimulate a more comprehensive investigation of this fascinating issue. Future work will want to explore why it is - in a given cultural setting - that certain strategies succeed brilliantly in eliciting and sustaining emotional commitment whereas others fail miserably. We will also want to understand the ways in which emotional appeals and responses may vary systematically across divisions of class, age, gender and local culture. Of further interest will be the relationship that different emotional states-hope, fear, regret, shame, anger, and so forth-may bear to different types of revolutionary (and post-revolutionary) action. As perhaps the world's most experienced and effective practitioners of emotionally charged mass mobilization, Mao and his latter-day lieutenants warrant the serious attention of social scientists both inside and outside the China field. ${ }^{16}$

A perspective highlighting the role of emotions in revolutionary mobilization does not supplant alternative explanations of revolutionary success. But it may allow us better to appreciate the ways in which factors such as ideology, organization, symbolism, class 
cleavages, and international influences must be suffused with emotional impact if they are to have the power to move ordinary people to revolutionary action.

\section{ENDNOTES}

${ }^{1}$ Recent anthropological and psychiatric studies of Chinese communities indicate, however, that Chinese (like other people) are both sociocentric and egocentric (Kleinman and Kleinman, 1997).

${ }^{2}$ See Esherick and Wasserstrom (1994) for the impact of this theatrical tradition on the Tiananmen Uprising of 1989.

${ }^{3}$ Hinton (1967: chapter 36) provides a telling example of the manner in which grassroots cadres could intervene to temper mass enthusiasm for revenge.

${ }^{4}$ As Mao wrote in his Hunan report, "A revolution is not a dinner party, or writing an essay, or painting a picture, or doing embroidery; it cannot be so temperate, kind, courteous, restrained and magnanimous ... Without using the greatest force, the peasants cannot possibly overthrow the deep-rooted authority of the landlords.... The rural areas need a mighty revolutionary upsurge, for it alone can rouse the people in their millions to become a powerful force."

${ }^{5}$ In this sense, violence could perform a function similar to that of speaking out the "hidden transcript;" i.e., giving voice to sentiments that had formerly been exchanged only outside the hearing range of the authorities (Scott 1990).

${ }^{6}$ As Vera Schwarcz (1997) has noted, speaking bitterness could also have negative effects on participants.

${ }^{7}$ Ding Ling (1954) is a fictional, yet historically accurate, narrative that highlights the importance of emotion work in carrying out land reform.

${ }^{8}$ Of course, moral economists have long emphasized the importance of such sentiments in generating popular protest. See, for example, Thompson (1971). A recent review of this approach to collective action can be found in Randall and Charlesworth (1999).

${ }^{9}$ Unless otherwise noted, the following discussion is taken from an internal-circulation bulletin published by the Shanghai trade union, entitled Gongyun qingkuang [Labor movement situation]. Labeled "top secret," it was intended for leading cadres within the union. Numbers 65 (May 5, 1951), 66 (May 5, 1951) and 69 (May 17, 1951) contain detailed descriptions of the proper procedures for holding accusation meetings. The materials are held in the Shanghai Municipal Archives, \#C1-2-397.

${ }^{10}$ Robert Lifton (1963: 393-395) traces the beginnings of thought reform back to Communist efforts to win over military prisoners in the 1920s; however, as he points out, it was only with the zhengfeng of 1942-1944 that these procedures became systematized.

${ }^{11}$ See also Chow (1967: 99-116) for a description of the students' resort to ritualistic shaming and violent confrontation as a strategy for heightening public emotions during the May Fourth Movement.

${ }^{12}$ Here one is tempted to draw parallels to the hysteria that swept adolescent girls, in particular, during the Salem witch trials. Arthur Miller's The Crucible provides a riveting dramatic recreation.

${ }^{13}$ Reddy (1997: 327) argues that poststructuralist theories fail to capture "the two-way character of emotional utterances and acts, their unique capacity to alter what they "refer" to or what they "represent" - a capacity which makes them neither "constative" nor "performative" utterances, but a third type of communicative utterance entirely, one that has never received adequate theoretical formulation." See also Reddy (1999).

${ }^{14}$ Kenez's (1985) thoughtful study suggests that, despite Lenin's stress on agitation and propaganda techniques, mass struggle sessions were not a part of the Soviet repertoire. See also Yu (1964) for an argument that, Soviet influence notwithstanding, the Chinese Communists themselves developed many distinctive forms of mass mobilization

${ }^{15}$ Organized mourners had also played a role in rural rebellion. A group operating in North China in the early twentieth century, known as the Mourning Clothes Society, was famous for unnerving its opponents by performing three kowtows and weeping loudly (the traditional mourning ritual) before engaging in battle. See Perry (1980: 204).

${ }^{16}$ The Chinese Communists do not stand alone in this endeavor, of course. For a study of ways in which the Nazis drew upon emotional religious experiences to mobilize the German masses against Jews and Communists (as well as against the Weimar state), see Kershaw (1999).

\section{REFERENCES}

Aminzade, Ronald, and Doug McAdam. 2001. "Emotions and Contentious Politics." In Aminzade et.al., eds., Silence and Voice in the Study of Contentious Politics. New York: Cambridge University Press.

Apter, David E., and Tony Saich. 1994. Revolutionary Discourse in Mao's Republic. Cambridge, MA: Harvard University Press.

Calhoun, Craig. 1994. Neither Gods nor Emperors: Students and the Struggle for Democracy in China. Berkeley: University of California Press. 
Central Archives, ed. 1989-90. Zhonggong zhongyang wenjian xuanji [Collection of CCP Central Documents]. Beijing: Central Party School.

Chen, Yung-fa. 1986. Making Revolution: The Communist Movement in Eastern and Central China, 1937-1945. Berkeley: University of California Press.

Chen, Hansheng, Xue Muqiao, and Ma Hefa, eds. 1985. Jiefangqian de Zhongguo nongcun [Chinese villages before Liberation], volume 1. Beijing: Zhongguo zhanwang chubanshe.

Chesneaux, Jean. 1973. Peasant Revolts in China. New York: Norton.

Chow, Tse-tung. 1967. The May Fourth Movement: Intellectual Revolution in Modern China. Stanford: Stanford University Press.

Cialdani, Robert B. 1993. Influence: The Psychology of Persuasion. New York: Quill/W. Morrow.

Cohen, Paul A. 2002. "Remembering and Forgetting National Humiliation in TwentiethCentury China." Twentieth-Century China 27 (2).

Crook, Isabel and David. 1979. Ten Mile Inn: Mass Movement in a Chinese Village. New York: Pantheon Books.

Ding, Ling. 1954. The Sun Shines over the Sangkan River. Beijing: Foreign Languages Press.

Dirlik, Arif. 1991. Anarchism in the Chinese Revolution. Berkeley: University of California Press.

Endicott, Stephen. 1991. Red Earth: Revolution in a Sichuan Village. New York: New Amsterdam Books.

Esherick, Joseph W. 1987. The Origins of the Boxer Uprising. Berkeley: University of California Press.

Esherick, Joseph W. and Jeffrey N. Wasserstrom. 1994. "Acting Out Democracy: Political Theater in Modern China." In Jeffrey N. Wasserstrom and Elizabeth J. Perry, eds., Popular Protest and Political Culture in Modern China. Boulder: Westview Press.

Fitzpatrick, Sheila. 1999. Everyday Stalinism: Ordinary Life in Extraordinary Times, Soviet Russia in the 1930s. New York: Oxford University Press.

Galbiati, Fernando. 1985. Peng Pai and the Hai-Lu-Feng Soviet. Stanford: Stanford University Press.

Gamson, William A., "The Social Psychology of Collective Action." In Aldon Morris and Carol McClurg Mueller, eds. 1992. Frontiers in Social Movement Theory, pp. 53-76. New Haven: Yale University Press.

Gao, Yuan. 1987. Born Red: A Chronicle of the Cultural Revolution. Stanford: Stanford University Press.

Gough, Hugh. 1998. The Terror in the French Revolution. New York: St. Martin's Press. Guomindang Central Committee, ed. 1954. Minyun ganbu shouce [Cadre handbook on popular movements]. Taipei.

Hinton, William. 1967. Fanshen: A Documentary of Revolution in a Chinese Village. New York: Monthly Review Press.

Hofheinz, Jr., Roy. 1977. The Broken Wave: The Chinese Communist peasant movement, 1922-1928. Cambridge: Harvard University Press.

Hochschild, A.R. 1979. "Emotion Work, Feeling Rules and Social Structure," American Journal of Sociology 85: 551-75.

Huang, Shu-min. 1989. The Spiral Road: Change in a Chinese Village Through the Eyes of a Communist Party Leader. Boulder: Westview Press.

Hung, Chang-tai. 1994. War and Popular Culture: Resistance in Modern China, 1937-1945. Berkeley: University of California Press.

Jing, Jun. 1999. "Villages Dammed, Villages Repossessed: A Memorial Movement in Northwest China." American Ethnologist 26 (2).

Johnson, Chalmers A. 1962. Peasant Nationalism and Communist Power: The Emergence of Revolutionary China. Stanford, CA: Stanford University Press.

Kataoka, Tetsuya. 1974. Revolution and Resistance in China: The Communists and the Second United Front. Berkeley: University of California Press.

Kenez, Peter. 1985. The Birth of the Propaganda State: Soviet Methods of Mass Mobilization, 19171929. Cambridge: Cambridge University Press.

Kershaw, Ian. 1999. Hitler, 1889-1936: Hubris. New York: W.W. Norton.

Kleinman, Arthur, and Joan Kleinman. 1997. "Moral Transformation of Health and Suffering in Chinese Society." In Allan M. Brandt and Paul Rozin, eds., Morality and Health. New York: Routledge. 
Li, Dazhang. 1942. "Dizhanqu yu jiedi gongzuo fangzhen yu zhengce" [Plans and policies for work in enemy-occupied zones]. (In Bureau of Investigation archives, Taipei)

Liang, Heng, and Judith Shapiro. 1983. Son of the Revolution. New York: Vintage.

Lifton, Robert Jay. 1963. Thought Reform and the Psychology of Totalism: A Study of Brainwashing in China. New York: W.W. Norton.

Liu, Xiaobo. 1994. "Revolution, That Holy Word." In Elizabeth J. Perry and Jeffrey N. Wasserstrom, eds., Popular Protest and Political Culture in Modern China. Boulder, CO: Westview Press.

MacKerras, Colin. 1975. The Chinese Theater in Modern Times. Amherst, MA: University of Massachusetts Press.

Madsen, Richard. 1984. Morality and Power in a Chinese Village. Berkeley: University of California Press.

Mao Zedong. 1971. "Report on an Investigation of the Peasant Movement in Hunan," Selected Readings from the Works of Mao Tsetung. Beijing: Foreign Languages Press.

1971. "Talks at the Yenan Forum on Art and Literature," Selected Readings.

Mo Wenhua. 1991. "Jiefang zhanzheng shiqi Liaodong junqu de zhengzhi gongzuo" [Political work in the Liaodong military zone during the war of liberation]. Zhonggong dangshi ziliao [Chinese Communist Party history materials], number 39.

Moore, Jr., Barrington. 1966. Social Origins of Dictatorship and Democracy: Lord and Peasant in the Making of the Modern World. Boston: Beacon Press.

Munro, Donald J. 1977. The Concept of Man in Contemporary China. Ann Arbor: University of Michigan Press.

Myrdal, Jan. 1965. Report from a Chinese Village. New York: Pantheon.

North, Robert C. 1952. Kuomintang and Chinese Communist Elites. Stanford: Stanford University Press.

Pan Zhenwu. 1962. "Yi Hongyijuntuan xuanchuandui" [Remembering the propaganda team of the Red Number One Military Troupe]. In Editorial Committee of Collected Essays Commemorating Thirty Years of the Chinese Peoples' Liberation, ed., Xinghuo liaoyuan [A single spark can light a prairie fire], volume 2. Beijing: People's Literature Press.

Pepper, Suzanne. 1978. Civil War in China: The Political Struggle, 1945-1949. Berkeley: University of California Press.

Perry, Elizabeth J. 1980. Rebels and Revolutionaries in North China, 1845-1945. Stanford: Stanford University Press.

.2000. "Reinventing the Wheel? The Suppression Campaign against Falun Gong." Harvard China Review.

. Forthcoming. "Workers' Patrols in the Chinese Revolution: A Case of Institutional Inversion." In William C. Kirby, ed., Realms of Freedom in Modern China. Stanford, CA: Stanford University Press.

Randall, Adrian and Andrew Charlesworth, eds. 1999. Moral Economy and Popular Protest: Crowds, Conflicts and Authority. New York: St. Martin's Press.

Reddy, William. 1997. "Against Constructionism: The Historical Ethnography of Emotions." Current Anthropology. 38(3).

. 1999. "Emotional Liberty: Politics and History in the Anthropology of Emotions." Cultural Anthropology.14(2): 256-288.

Schwarcz, Vera. 1997. In Arthur Kleinman, Veena Das and Margaret Lock, eds., Social Suffering. Berkeley: University of California Press.

Scott, James C. 1990. Domination and the Arts of Resistance: Hidden Transcripts. New Haven: Yale University Press.

Selden, Mark. 1971. The Yenan Way in Revolutionary China. Cambridge, MA: Harvard University Press.

Shanghai Municipal Archives, \#Q6-31-132 (October 30, 1947) secret directive of the GMD Shanghai Workers' Welfare Committee.

Skocpol, Theda. 1979. States and Social Revolutions: A Comparative Analysis of France, Russia and China. Cambridge: Cambridge University Press.

Snow, Edgar. 1963. Red Star over China. New York: Random House.

Solomon, Richard. 1971. Mao's Revolution and the Chinese Political Culture. Berkeley, CA: University of California Press. 
Stunt, Timothy C. F. 2000. From Awakening to Secession: Radical Evangelicals in Switzerland and Britain, 1815-35. Edinburgh: T\&T Clark.

Taylor, George E. 1940. The Struggle for North China. New York, International Secretariat, Institute of Pacific Relations.

Taylor, Verta. 1995. "Watching for Vibes: Bringing Emotions into the Study of Feminist Organizations." In Myra Marx Ferree and Patricia Yancey Martin, eds., Feminist Organizations: Harvest of the New Women's Movement, pp. 22-33. Philadelphia, PA: Temple University Press.

Thompson, E. P. 1971. "The Moral Economy of the English Crowd in the $18^{\text {th }}$ Century." Past and Present, 50: 76-136.

Turner, Victor Witter. 1974. Dramas, Fields, and Metaphors: Symbolic Action in Human Society. Ithaca, NY:Cornell University Press. . 1982. From Ritual to Theatre:The Human Seriousness of Play. New York: PAJ Publications.

Wang Youqin. 1995. "1966: Xuesheng da laoshi de geming” [1966: The revolution in which students beat up teachers], Ershiyi shiji shuangyuekan 31 (8).

Wasserstrom, Jeffrey N. 1991. Student Protests in Twentieth-Century China: The View from Shanghai. Stanford, CA: Stanford University Press.

White III, Lynn T. 1989. Policies of Chaos: The Organizational Causes of Violence in China's Cultural Revolution. Princeton, N.J.: Princeton University Press.

Writing Group on the Rectification of the Yenan Central Party School, ed. 1988. Yanan zhongyang dangxiao de zhengfeng jiaoxun [Lessons from the rectification movement at the Yanan Central Party School]. Beijing: Central Party School Press.

Yu, Frederick T.C. 1964. Mass Persuasion in Communist China. New York: Praeger.

Yue Daiyun and Carolyn Wakeman. 1985. To the Storm: The Odyssey of a Revolutionary Chinese Woman. Berkeley: University of California Press.

Zarrow, Peter. 1990. Anarchism and Chinese Political Culture. New York: Columbia University Press.

Zhang Ben, et al. 1953. "Shanghai guomian shiqichang gongren douzhengshi" [The history of labor struggles at Shanghai's Number Seventeen cotton mill], Shanghai gongren yundong lishi ziliao [Historical materials on the Shanghai labor movement]. Shanghai.

Zhang Raochu, et.al. 1958. Yanan zhengfeng huiyilu [A memoir of the Yanan rectification]. Harbin: Heilongjiang Peoples, Press.

Zhang Xiang'er. 1987. Xinshiqi sixiang zhengzhi gongzuo shouce [A handbook on political thought work in the new era]. Zhengzhou: Henan People's Press.

Zhong Xidong. 1957. Tantan dang de zhengfeng jingyan [Discussion of the party's rectification experience]. Shanghai: Shanghai People's Press. 